International Journal of Engineering \& Technology, 7 (4.38) (2018) 908-911
International Journal of Engineering \& Technology
WPC
Website: $w w w . s c i e n c e p u b c o . c o m / i n d e x . p h p / I J E T$
Research paper

\title{
Big Data Framework for Auditing Process
}

\author{
Siska P. Yudowati1, Andry Alamsyah2 \\ 1,2Faculty Economics and Business \\ Telkom University, Bandung, Indonesia
}

\begin{abstract}
An audit of financial report is a review of the organization financial statement that carried out by the independent and professional in their field which is the Auditor. The Big Data methodology offered a different approach compared to the current audit procedure, which mostly using manual process. Big Data equipped with learning capabilities and automation process in order to achieve better and faster result. Another advantage of using Big Data methodology is to provide comprehensive and multi-dimensional view of the problem. This paper provides a framework to incorporated auditing process and Big Data approach, specifically by mapping the internal and external data source to one of audit process stage, which is risk assessment process.
\end{abstract}

Keywords: Big Data, Audit, Risk Assessment.

\section{Introduction}

Data mining is the application of specific algorithms for extracting The process and the business overview from an organization or company can be seen in a financial report made by the management and as the party that is responsible for the financial report, the management needs the auditor as an independent party to audit the financial report because of the possibility that such financial report contain misstatements, to ensure the fairness in accordance with Accounting Standards and IFRS, the obligation to give the annual financial report to the government as the taxes supporting data and if it listed at the Indonesian Stock Exchange then they should give the financial report periodically.

In digital economy era, currently information related to the economic and the company business process in the form of data can be obtained through the internet, the website, and social media such as; blog, Facebook, Instagram, Path and WhatsApp. Data that spread over derived from official sources as well as the unofficial one arrayed in structured (internal data) and also unstructured (external data).

Audit Data Analytics (ADA) is the analysis of data underlying financial statements, together with related financial or nonfinancial information, for the purpose of identifying the potential misstatements or risks of material misstatement (Deniz et all, 2015).

If information is in the form of data available in a very high amount so that the merger of the data will form groups of data that can give a pattern or trend, these pattern or trend which will give a new view towards the implied information in the data beforehand. The need for analysis, interpretation or the handling of a pattern or trend of the data known as Big Data.

Big Data analytics allow the auditor become capable to identify financial reporting, fraud and operational business risk and adjust their approach to give more relevant audit (EY Reporting: Issue 9, 2015).

Big data framework is the frame of mind that seen the data from the size, the diversity, the speed, the value, and the processing complexity. Big Data Framework incorporated internal and external data to audit process. Most internal data are in the form of structured data, where we can find easily in large-scale data warehouse. Meanwhile, the external data sources are in the unstructured form, for example: data from the news, conversation data on social media, forum, and the other media online. Both structured and unstructured data can be processed using data analytics model such as data mining, social network analysis, and text mining.

The Big Data approach has the advantages with its ability to learn data pattern. The data pattern found could be used as a learning so that they can predict a pattern or a certain behavior in the future. An example is in the classification model, how we can find the pattern of a positive or negative opinion, with the identification of certain features, then we can group the new opinion data into positive or negative class. Another model is the extraction of important information from documents based on keywords, entities, summaries, and other models in the Text Mining family group. Text Mining is a method of backbones for the extraction of unstructured data from the Internet. In general, there are other important models in Big Data framework for example regression model, cluster, association, and others.

\section{State of the Art Auditing Process}

The Risk Based Audit Process

In 2014 Indonesian Institute of Accountants (IIA) decided to adopt on International Standard of Auditing (ISA) and the other professional standards secreted by the International Federation of Accountants (IFAC). The difference SPPA (Standards of a Profession Public Accountant) with ISA such as the emphasis on risk in each of the stage of the audit. Thus, the ISA-based audit is a riskbased audit.

Risk-based audit containing three key stages. The first stage is to assess the risk, the second stage is responding to the risk and the third stage is reporting. In the first stage of the audit process that is risk assessment, the auditor performs the risk assessment procedure and in this stage the auditor identifies and assesses the risk of material misstatement (ISA 200.13) in financial report, by under- 
standing the entity, among others are the purpose of entity, the external factor, the nature of entity, accounting policy, the measurement of financial performance and internal control (Tuanakotta, 2015).

There are two main classifications of risk, namely business risk and fraud risk. Manipulation have some meaning such as manipulation or fraud is deliberate acts by one or more persons within the management team, those responsible for the governance, employees, third parties, by deception to gain unfair advantage under the law (ISA 240).

The first step in the risk assessment process is collecting and update as much as possible the relevant information about the entity This information provides the important frame of reference to identify and assess the risk factors that might exist. Information about the entity and its environment can be obtained from internal and external sources. Internal sources for financial information such as financial statements, budget, reports, performance measurement, tax returns, accounting policies and considerations or estimates. While internal sources for non-financial information such as vision, values, objectives and strategy, organizational structure, job description, human resources documents, performance indicators and policies and manual procedures. External sources for financial information for example information from the Internet, industry information, competitive intelligence, credit rating agencies, creditors, government and media and other external sources. While external sources for non-financial information such as information from the internet, trade association data, industry forecast, government and media articles.

After knowing the sources of risk as well as assessing the likelihood of risk being the cause of material misstatements in the financial report, this process will provide guidance and information needed to direct its audit efforts to areas where risk is high or needs special attention (Tuanakotta, 2015).

\section{Integrate Big Data Framework into Audit Process}

Looking at the Big Data developments, auditors in carrying out the audit process make adjustments in order to achieve better audi results. One of the risk assessment procedures is analytical procedures. To perform this procedure, the auditor doing several tasks such as determining the relationships among the data, comparing, finding unexpected patterns and evaluating the results. In essence, those tasks are similar to an audit investigation step called analytical review.

Through this process it is expected that the auditor will obtain an overview or description of the various possible risks that exist in the entity that is not obtained if only perform analytical procedures on internal data, one of which the possibility of fraud risk financial and non-financial reports and can identify and provide further analysis against high risk. Information through Big Data also helps the auditor to provide more comprehensive and in-depth evidence because the analytical procedure using Big Data requires deeper analysis and research that is similar to what investigative auditors do.

In Big Data Framework (Fig.1) it begins with Large data computation where each information and distribution of information in column of information source of Big Data external and internal (Table 1 and 2) in the form of data processed one by one with other information. It then identifies every word inside the Big Data's external and internal information so that it becomes a keyword in a more structured form at the Text mining/extraction stage. When the keyword has become the key information then mapping the existing information on external and internal Big Data sources and matching one with the other so as to see the similarity and relationship between information at the Matching automation stage. The data or information that has been identified is processed one by one and associated with other information so that the pattern or trend and anomaly can be seen at this stage that is Pattern
Identification. Machine Learning is a stage where when the pattern or trend has been mapped and analysis has been done then the new information generated into a learning for further analysis.

Several scenarios are shown in this paper to assists understanding the role of Big Data in the audit process.

Table 1. Mapping of External Information Sources, Big Data External Information Resources and Identify Risks to Entities

\begin{tabular}{|c|c|c|}
\hline $\begin{array}{c}\text { External } \\
\text { Infor- } \\
\text { mation } \\
\text { Sources }\end{array}$ & $\begin{array}{l}\text { Big Data External Infor- } \\
\text { mation Sources }\end{array}$ & Identify Risks to Entities \\
\hline $\begin{array}{l}\text { Industry } \\
\text { infor- } \\
\text { mation }\end{array}$ & $\begin{array}{l}\text { The movement of sales and } \\
\text { financial ratios of similar } \\
\text { industries }\end{array}$ & $\begin{array}{l}\text { Risk of sales value manipu- } \\
\text { lation and financial ratios }\end{array}$ \\
\hline $\begin{array}{l}\text { Industry } \\
\text { forecast }\end{array}$ & Stock price movements & $\begin{array}{l}\text { Risk of manipulation of the } \\
\text { company's profit presenta- } \\
\text { tion }\end{array}$ \\
\hline \multirow{3}{*}{$\begin{array}{l}\text { Infor- } \\
\text { mation } \\
\text { from The } \\
\text { Internet }\end{array}$} & $\begin{array}{l}\text { Recommendations on blogs } \\
\text { and testimonials }\end{array}$ & $\begin{array}{l}\text { The risk of manipulation to } \\
\text { raise the value of the firm }\end{array}$ \\
\hline & $\begin{array}{l}\text { Facebook, Twitter, path and } \\
\text { Instagram }\end{array}$ & $\begin{array}{c}\text { Individual information } \\
\text { indicated to conduct trans- } \\
\text { actions with related parties }\end{array}$ \\
\hline & $\begin{array}{l}\text { The company's official } \\
\text { website }\end{array}$ & $\begin{array}{c}\text { Risk of product and service } \\
\text { inconsistencies and busi- } \\
\text { ness strategy }\end{array}$ \\
\hline $\begin{array}{l}\text { Trade } \\
\text { Associa- } \\
\text { tion Data }\end{array}$ & $\begin{array}{l}\text { Information disclosure of } \\
\text { BEI (suspension, restructur- } \\
\text { ing, corporate action, etc) }\end{array}$ & $\begin{array}{l}\text { Risks to business continui- } \\
\text { ty and business change }\end{array}$ \\
\hline $\begin{array}{l}\text { Govern- } \\
\text { ment }\end{array}$ & $\begin{array}{l}\text { Macroeconomics: policy, } \\
\text { legislation, inflation and } \\
\text { interest rates }\end{array}$ & $\begin{array}{l}\text { Risks to economic change } \\
\text { (crisis, recession, booming) }\end{array}$ \\
\hline $\begin{array}{c}\text { Credit } \\
\text { Rating } \\
\text { Agencies }\end{array}$ & Credit rating agencies & The risk of a default entity \\
\hline \multirow{2}{*}{$\begin{array}{l}\text { The Media } \\
\text { and Other } \\
\text { External } \\
\text { Sources }\end{array}$} & $\begin{array}{c}\text { Electronic news media and } \\
\text { third parties analysis ( CNN, } \\
\text { detik.com, etc) }\end{array}$ & \multirow{2}{*}{$\begin{array}{l}\text { Corporate governance risk, } \\
\text { and poor reputation }\end{array}$} \\
\hline & $\begin{array}{l}\text { Articles and recommenda- } \\
\text { tions from securities firms }\end{array}$ & \\
\hline
\end{tabular}

Table 2 Mapping of Internal Information Sources, Big Data Internal Information Resources and Identify Risks to Entities

\begin{tabular}{|c|c|c|}
\hline $\begin{array}{l}\text { Internal } \\
\text { Information } \\
\text { Sources }\end{array}$ & $\begin{array}{l}\text { Big Data Internal } \\
\text { Information Sources }\end{array}$ & Identify Risks to Entities \\
\hline $\begin{array}{l}\text { Financial } \\
\text { Report }\end{array}$ & $\begin{array}{l}\text { Company financial } \\
\text { report last } 3-5 \text { years }\end{array}$ & $\begin{array}{l}\text { Risk of sales value manipula- } \\
\text { tion, profit presentation and } \\
\text { financial ratios }\end{array}$ \\
\hline \multirow{3}{*}{$\begin{array}{l}\text { Budget and } \\
\text { Realization } \\
\text { Report }\end{array}$} & \multirow{3}{*}{$\begin{array}{l}\text { Budget reports and } \\
\text { periodic realization } \\
\text { (monthly, semiannu- } \\
\text { al) }\end{array}$} & $\begin{array}{c}\text { Risks of failing to anticipate } \\
\text { needs (resources, labor and } \\
\text { technology) }\end{array}$ \\
\hline & & $\begin{array}{l}\text { The risk of weak internal con- } \\
\text { trol resulting in overbudget }\end{array}$ \\
\hline & & $\begin{array}{c}\text { The risk of weak supervision on } \\
\text { budgeting (inefficient) }\end{array}$ \\
\hline Tax Report & $\begin{array}{l}\text { Company tax report } \\
\text { last 3-5 years }\end{array}$ & Risk minimize the tax burden \\
\hline $\begin{array}{l}\text { Accounting } \\
\text { Policy Used }\end{array}$ & $\begin{array}{c}\text { A decree from offi- } \\
\text { cial financial regard- } \\
\text { ing accounting policy } \\
\text { last 3-5 years } \\
\end{array}$ & $\begin{array}{l}\text { The risk of applying incon- } \\
\text { sistent and appropriate account- } \\
\text { ing policies }\end{array}$ \\
\hline \multirow{4}{*}{$\begin{array}{l}\text { Performance } \\
\text { Assessment, } \\
\text { The Job } \\
\text { Description } \\
\text { and Docu- } \\
\text { ments of } \\
\text { Human Re- } \\
\text { sources }\end{array}$} & $\begin{array}{l}\text { Periodic reports } \\
\text { (monthly, semiannu- } \\
\text { al, апnиal) }\end{array}$ & $\begin{array}{c}\text { Performance measurement risks } \\
\text { and job descriptions are not } \\
\text { performed by management to } \\
\text { achieve goals }\end{array}$ \\
\hline & \multirow{2}{*}{$\begin{array}{l}\text { A manual and the } \\
\text { company policy } \\
\text { regarding job descrip- } \\
\text { tion in the organiza- } \\
\text { tion }\end{array}$} & $\begin{array}{c}\text { Performance measurement risk } \\
\text { is not used to correct problems } \\
\text { in business operations }\end{array}$ \\
\hline & & $\begin{array}{c}\text { The risk of having employees in } \\
\text { important positions with less } \\
\text { ability }\end{array}$ \\
\hline & $\begin{array}{l}\text { employees CV in- } \\
\text { formation report }\end{array}$ & $\begin{array}{l}\text { Risk there is relationship be- } \\
\text { tween employees and related } \\
\text { party transactions }\end{array}$ \\
\hline
\end{tabular}




\begin{tabular}{|c|c|c|}
\hline $\begin{array}{c}\text { Internal } \\
\text { Information } \\
\text { Sources }\end{array}$ & $\begin{array}{c}\text { Big Data Internal } \\
\text { Information Sources }\end{array}$ & Identify Risks to Entities \\
\hline \multirow{3}{*}{$\begin{array}{l}\text { Vision, Mis- } \\
\text { sion, Values } \\
\text { And Corpo- } \\
\text { rate Culture }\end{array}$} & $\begin{array}{l}\text { Report on the imple- } \\
\text { mentation of the } \\
\text { program to keep the } \\
\text { company's values } \\
\text { (outing, bounding) } \\
\text { done at least } 1 \text { times } \\
\text { per year during the } \\
\text { last } 3-5 \text { years }\end{array}$ & $\begin{array}{l}\text { The risk of non-implementation } \\
\text { of corporate culture }\end{array}$ \\
\hline & $\begin{array}{l}\text { The report feedback } \\
\text { from customers last } \\
\text { 3-5 years }\end{array}$ & $\begin{array}{c}\text { The risk of a poor relationship } \\
\text { with customers (loss of custom- } \\
\text { ers) }\end{array}$ \\
\hline & $\begin{array}{l}\text { Loan payment report } \\
\text { and late payment fine } \\
\text { (letter of reprimand } \\
\text { from funder) }\end{array}$ & $\begin{array}{l}\text { The risk of a poor relationship } \\
\text { with the funder }\end{array}$ \\
\hline \multirow{2}{*}{$\begin{array}{l}\text { Organiza- } \\
\text { tional Struc- } \\
\text { ture }\end{array}$} & \multirow{2}{*}{$\begin{array}{l}\text { The organizational } \\
\text { structure and plan- } \\
\text { ning management } \\
\text { strategies last } 3-5 \\
\text { years }\end{array}$} & $\begin{array}{l}\text { Risk complexity or complexity } \\
\text { within the organizational struc- } \\
\text { ture }\end{array}$ \\
\hline & & $\begin{array}{l}\text { The risk of changing the organi- } \\
\text { zational structure for key posi- } \\
\text { tions }\end{array}$ \\
\hline \multirow{2}{*}{$\begin{array}{l}\text { Policies and } \\
\text { manual pro- } \\
\text { cedures }\end{array}$} & \multirow[b]{2}{*}{$\begin{array}{l}\text { The internal auditor } \\
\text { report }\end{array}$} & $\begin{array}{l}\text { The risk of internal control is } \\
\text { weak or not working }\end{array}$ \\
\hline & & $\begin{array}{l}\text { The risk of supervision and } \\
\text { security of assets by manage- } \\
\text { ment is weak }\end{array}$ \\
\hline
\end{tabular}

Scenario:

1. The result of an analytical review is known that the sale and purchase of a company is too high in the year of the audit.

After an interview with the management, it is known the company is planning expansion and growth of the company. With the application of Big Data Framework then the information increase in sales and purchases can be clarified whether it is fair or not. Through this approach it can be seen that sales and purchases made are mostly transactions between parties who have relationships or relate and not in line with the development of the industry at that time. The company did so in order to raise the credit rating in the eyes of the funders. So there is risk of manipulation of financial statements.

2. The budget report provided by management to the auditor displays a reasonable budget in the year of the audit. Compared with the realization report, there is a significant difference, the amount stated in the realization report shows the amount exceeded budgeted, but the monthly performance report shows the decreasing performance in the current year. The application of Big Data Framework will clarify the amount information on the realization report whether fair or not. Through this approach it can be known monthly performance reports, sales trends, stock price movements of both entities and similar industries, corporate policy and government policy is in line with the realization report. If not aligned such as the company's monthly performance report decreased, which implies that the company's sales in the year decreased. However, sales trends increase as well as similar industry stock prices coupled with government policies supporting the industry. Then the budget is not allocated effectively by the company or there is risk of weak internal control.

3 . Recommendations from stock analyst at one of the leading websites suggest buying an entity's share in a given period as the company will make an acquisition with one of the leading start-up companies. The application of Big Data Framework will assist the auditor in clarifying the information on those recommendations. Through this approach it can be seen that the stock analyst's recommendation whether supported by information related to the entity. If during the period of information disclosure from the Indonesia Stock Exchange is not available, then the financial report show that the company has financial difficulties during the last 4 years, the creditor once sent a letter of reprimand and fines and information available on social media implies that stock analyst who recommend shares of entities has a family rela- tionship with the management. Then there is a risk of poor governance and reputation.

The Big Data Framework approach provides a deeper understanding of the entity and its environment for risk identification.

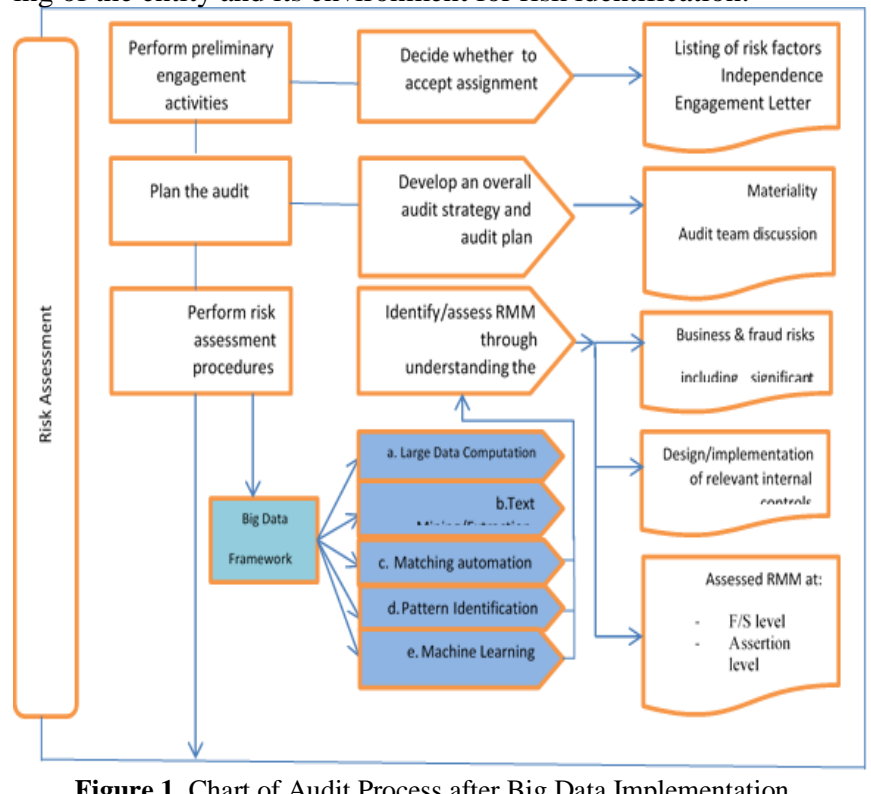

Figure 1. Chart of Audit Process after Big Data Implementation

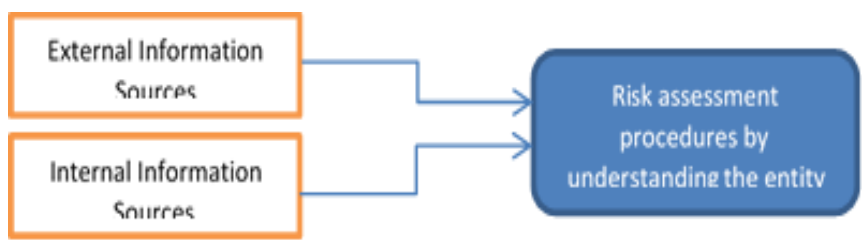

Figure 2. Before Big Data Implementation

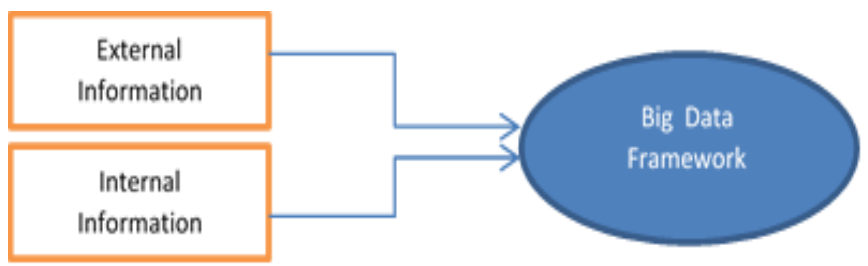

Figure 3. After Big Data Implementation

Fig 1. Demonstrate the application of Big Data Framework (processes a, b, c, d and e) in the risk-based audit process at the risk assessment stage. Prior to the application of the Big Data Framework (Fig.2), when the auditor performs the assessment procedure, the auditor will conduct an analysis based on the availability of existing information and take a longer time in carrying out an analysis to understand the entity being audited, then proceed by reviewing and assessing the risk of material misstatement in the financial report. After the application of the Big Data Framework (Fig 3.) in the risk-based audit process, when the auditor performs the risk assessment procedures, all external and internal information (Table 1 and 2) will be processed and then analyzed using Big Data Framework, analysis results in the form of pattern or anomalous trends which will be the basis for the identification and assessment of risk of material misstatement in the financial report.

\section{Conclusions}

The framework of risk-based audit process especially in the risk assessment stage can incorporated Big Data framework. The methodology in obtaining data for identification of entity risk is similar with previous or standard procedure without Big Data framework, but the resulting information becomes comprehensive, because it involves more data, and it has the capabilities to find unexpected data patterns or insight. 


\section{References}

[1] Alvin A. Arens, et all. (2008). Auditing dan Jasa Assurance, Ed. 12. Erlangga.

[2] Gojko et all.(2013). Integrated Forensic Accounting Investigative Process Model in Digital Environment. International Journal of Scientific and Research Publications, Vol.3.

[3] Soekrisno A.,(2012). Auditing Petunjuk Praktis Pemeriksaan Akuntan oleh Akuntan Publik. Ed. 4. Salemba Empat.

[4] Theodorus M, T.(2010). Akuntansi Forensik dan Audit Investigasi. Ed.2. Salemba Empat

[5] Theodorus M, T.(2015). Audit Kontemporer. Salemba Empat

[6] Ernest and Young. (April, 2015). How big data and analytics are transforming the audit.

[7] http://www.ey.com/gl/en/services/assurance/ey-reporting-issue-9how-big-data-

[8] and-analytics-are-transforming-the-audit (downloaded December 3 , 2016)

[9] Murphy, Maria and Ken Tysiac. (April 14, 2015). Data analytics helps auditors gain deep insight.

[10] http://www.journalofaccountancy.com/issues/2015/apr/dataanalytics-for-auditors.html (downloaded December 3, 2016)

[11] PWC Business Analytics. (2013).Where have you been all my life? Unlock the value in Big Data.

[12] https://www.pwc.com.au/consulting/assets/publications/australiabig-data-pov.pdf (downloaded December 3, 2016)

[13] Vasarhelyi, Miklos A. (December 1, 2015). Big data and the Audit Data Standard: forensic accounting implications.

[14] http://raw.rutgers.edu/docs/fraud/12fraud/Big\%20Data\%20and\%20 the $\% 20$ audit $\% 20$ data $\% 20$ standard $\% 20$ forensic $\% 20$ implications.pdf (downloaded December 3, 2016)

[15] Wong, Damien. (December 21, 2017). "Apa "Rahasia" Memanfaatkan Big Data?". http://tekno.kompas.com/read/2013/12/21/0904593/Apa.Rahasia.M emanfaatkan.Big.Data. (downloaded December 3, 2016) 